\title{
MARRIAGE AGREEMENT FOR THE JOINT ASSETS IN MIXED COUPLE MARRIAGE ACCORDING IN INDONESIA BOOK OF CIVIL LAW NUMBER 1 OF 1974 POST DECISION OF THE COURT OF CONSTITUTION NUMBER 69/PUU-XIII/2015
}

\author{
Prof. Dr. Titik Triwulan Tutik ${ }^{* 1} 凹$ \\ ${ }^{* 1}$ S.H, M.H, Faculty of Sharia and Law Sunan Ampel State Islamic University, Surabaya, Indonesia
}

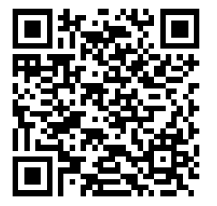

DOI: https://doi.org/10.29121/granthaalayah.v9.i1.2021.3119

Article Type: Research Article

Article Citation: Prof. Dr. Titik

Triwulan Tutik. (2021). MARRIAGE

AGREEMENT FOR THE JOINT

ASSETS IN MIXED COUPLE

MARRIAGE ACCORDING IN

INDONESIA BOOK OF CIVIL LAW

NUMBER 1 OF 1974 POST DECISION

OF THE COURT OF CONSTITUTION

NUMBER 69/PUU-XIII/2015.

International Journal of Research -

GRANTHAALAYAH, 9(1), 1-9.

https://doi.org/10.29121/granthaa

layah.v9.11.2021.3119

Received Date: 15 January 2021

Accepted Date: 31 January 2021

Keywords:

Mixed Marriage

Marriage Agreement

Joint Property

\section{ABSTRACT}

This study aims to analyze the position of the Marriage Agreement for Joint Treasures in Mixed Marriage from three sides of the law, namely Civil Law, Law Number 1 of 1974, and Constitutional Court Decree Number 69/PUU-XIII/2015.

Hypothesis: Decision of the Constitutional Court Number 69/PUU-XIII/2015 in line with Islamic law that prioritizes equal rights and obligations between husband and wife in terms of ownership of assets in marriage.

The method: used is normative (dogmatic) legal research, which is intended to find and formulate legal arguments, through analysis of the subject matter. While the approach used in this study there are 4 (four) types, namely: the statutory approach, comparative approach, conceptual approach, and case approach.

The results: of the study show that the Constitutional Court Decision Number 69/PUU-XIII/2015 has provided a practical solution in overcoming the problems of a Marriage Agreement on Joint Assets: First, a marriage agreement can be made before, during and after the marriage is implemented. Second, ratification of a marriage agreement may be by a notary public, and effective from the date of the marriage agreement, and may be revoked. Third, marriage agreements are binding on third parties, especially related to the position of joint property in the marriage. This means that, Indonesian citizens have the right to joint property in a mixed marriage as long as the marriage agreement states that. The ruling is in line with Islamic law that prioritizes equal rights and obligations between husband and wife in terms of ownership of assets in a marriage.

Conclusion: The legal consequences of the Constitutional Court Decision Number 69/PUU-XIII/2015 on the status of joint property made a marriage agreement after marriage which began since the marriage took place followed by the status of shared property becomes separate if both parties wish in the agreement, as well as assets to be obtained in the future remain the property of each party, without having to obtain a court decision regarding the separation of assets. This ruling is in accordance with Islamic law which prioritizes equal rights and obligations between husband and wife in terms of ownership of assets in marriage.

\section{INTRODUCTION}

Mixed marriages in Indonesian law, defined in Law Number 1 of 1974 concerning Marriage (hereinafter referred to as Marriage Law 1974), Article 57 reads:

(C) 2021 The Author(s). This is an open access article distributed under the terms of the Creative Commons Attribution License, which permits unrestricted use, distribution, and reproduction in any medium, provided the original author and source are credited. 


\section{Prof. Dr. Titik Triwulan Tutik}

"What is meant by mixed marriages in this law is a marriage between two people who in Indonesia are subject to different laws, due to differences in citizenship and one of the parties of Indonesian citizenship."

The definition means, that: (1) mixed marriages are marriages between two people of the same sex; (2) subject to different laws; and (3) have a different nationality and one of the parties (husband/wife) is an Indonesian citizen. Thus, mixed marriages that are recognized in the context of the rule of law in Indonesia are limited to differences in citizenship that are subject to different legal rules rather than religious as is common among celebrities today.

The existence of mixed marriages between Indonesian citizens and foreign citizens, for almost a half century of citizenship arrangements in referring to Law Number 62 of 1958 on Citizenship (hereinafter referred to as the Citizenship Act 1958). The problem is, that the 1958 Citizenship Law is no longer be able to accommodate the interests of the parties in mixed marriages, especially protection for wives and children. On July 11, 2006 that the Parliament passed a new Citizenship Act, Law No. 12/2006 (hereinafter referred to as the 2006 Citizenship Act).

The birth of the 2006 Citizenship Act gives new hope to those who are married to foreign nationality, although the pros and cons still arise, but in general the 2006 Citizenship Act allows the selection of citizenship for Indonesian women in the hope of providing new enlightenment in overcoming issues concerning the citizenship status of a wife of mixed marriages.

Based on the 2006 Citizenship Act, it clearly states that a wife does not automatically have to submit to the laws that apply to her husband. Conversely, a foreign woman who marries a male Indonesian citizen does not automatically obtain Indonesian citizenship, except if within a period of 3 (three) years after his marriage, stating the statement for that. 1

Even though the 2006 Citizenship Law has made a new breakthrough in terms of the marital status of husband and wife in mixed marriages, but other problems that arise in mixed marriages are related to property obtained during mixed marriages, if it is related to agreements in marriage.

Arrangement of assets obtained during marriage is regulated in different legal provisions (plurality), namely Civil Law, especially for non-Muslim citizens and for Muslim citizens the provisions of the Marriage Law 1974, Presidential Instruction Number 1 of 1991 about Compilation of Islamic Law in addition to applying Islamic Law itself.

According to the provisions of the Civil Law, basically the assets obtained during marriage become one, become joint property. In Article 119 of the Civil Law, since the marriage begin, there is a joint property between the husband and wife, as long as no other provisions are held in the marriage agreement. Joint assets, during the marriage, should not be abolished or changed with an agreement between husband and wife.

Furthermore, that after the dissolution of shared assets, their shared wealth is divided between husband and wife, or between their heirs, without question which party the goods came from. The provisions in the Civil Law are different from the provisions in the 1974 Marriage Law, Compilation of Islamic Law (KHI) and Islamic Law. These three rules basically divide the two types of assets obtained during marriage, namely; first, property obtained during marriage becomes joint property, and second, property inherited from each husband and wife and property obtained respectively as a gift or inheritance. ${ }^{2}$

Marriage Law 1974, regarding the matter of property in marriage is regulated in Article 35 which states that assets obtained during marriage become joint property. Meanwhile, the inheritance of each husband and wife and the property obtained by each as a gift or inheritance are under each supervision as long as the parties do not specify otherwise.

Based on the provisions of Article 35 of the 1974 Marriage Law, that assets obtained by inheritance or gifts cannot be categorized as joint assets. This provision is in line with Sura al-Nisa verse 32 which basically confirms that every man and woman has a part of what they are trying for themselves. This provision is reaffirmed, in KHI Articles 85, 86, and 87 which introduce the existence of inherited property (property of each husband and wife) in a marriage. ${ }^{3}$ And between the two assets (the property of each husband and wife) there will be no mixing. ${ }^{4}$ Husband and wife have full rights to their assets as long as the parties do not specify anything else in the marriage agreement. 5

\footnotetext{
1 See Article 26 paragraph (4) of the Citizenship Law

2 See Article 128 of the Civil Code

3 See Article 85 KHI

${ }^{4}$ See Article $86 \mathrm{KHI}$

${ }^{5}$ See Article $87 \mathrm{KHI}$

International Journal of Research -GRANTHAALAYAH
} 
Regarding mixed marriages, Indonesian citizens (WNI) who marry foreign citizens, after marriage, are indeed not allowed to have land rights in the form of Ownership Rights, Business Use Rights or Building Use Rights.

Article 35 of the Marriage Law of 1974 states that assets obtained during a marriage become joint property. So, there is a mixture of assets obtained after marriage, and the spouse (who is a foreign citizen) will also become the owner of the joint property. While referring to the provisions of Law Number 5 of 1960 concerning Basic Regulations on Agrarian Principles (PDPA Law 1960), foreigners must not have Ownership Rights, Business Permit or Building Use Rights.

Article 21 paragraph (1) and paragraph (3) of Law Number 5 of 1960 concerning Basic Regulations on Agrarian Principles (PDPA Law 1960) expressly states, that only Indonesian citizens can use property rights. And foreigners who after the entry into force of the 1960 PDPA Law who obtained property rights due to inheritance without a will or a mixture of assets due to marriage, likewise Indonesian citizens who lose their citizenship are required to release their citizenship within one year of the acquisition of that right or loss of citizenship. Furthermore Article 36 Paragraph (1) of the 1960 PDPA Law states that "those who can have the right to build are: (a). Indonesian citizens; and (b). a legal entity established under Indonesian law and domiciled in Indonesia."

Based on these provisions, that a citizen who is married to a foreigner, after marriage can no longer obtain the Right of Ownership, or Right to Build, or Cultivation rights, because it will be part of the joint assets that he has with his foreign national partners. On the basic of these provisions, if an Indonesian citizen wishes to retain land rights after marriage with a foreign national, the Indonesian citizen must make a marriage agreement or prenuptial agreement governing the separation of assets.

Provisions regarding marriage agreements for property obtained during the marriage underwent quite revolutionary changes after the Constitutional Court Decision (hereinafter referred to as MK) Number 69/PUUXIII/2015 invalidated several provisions in the Marriage Law 1974 and Law Number 5 of 1960 concerning Regulations Basic Principles of Agraria (read, PDPA Act 1960) and declared contradictory to the 1945 Constitution of the Republic of Indonesia (hereinafter referred to as the 1945 Constitution of the Republic of Indonesia). ${ }^{6}$ According to the Court, that a marriage agreement may be made at the time, before, or during marriage.

Letter of the General Director of Population and Civil Registration of the Ministry of Home Affairs Number 472.2/5876/DUKCAPIL dated May 19, 2017, a marriage agreement can be made before, during and during the marriage with a notary deed and reported to the Implementing Agency or the Citizenship Implementation Unit ("UPT")) Implementing Agency. Regarding the reporting of the marriage agreement, the Civil Registration Officer at the Implementing Agency or the UPT of the Implementing Agency makes a marginal note on the register of the deed and the marriage certificate.

Consideration of the Constitutional Court Decision Number 69/PUU-XIII/2015 dated October 26, 2016, stipulates that Article 29 paragraph (1) of the 1974 Marriage Law is interpreted "At the time, prior to being carried out or during the marriage contract both parties upon mutual agreement may submit a written agreement. which is validated by the marriage registrar or notary public, after which the contents also apply to third parties as long as the third party is involved". Thus, regardless of the marital procedure / administration, Indonesian citizens who engage in mixed marriages (married to foreigners) in order to obtain legal protection especially for assets obtained during marriages due to the provisions of the PDPA law 1960 Act can make marriage agreements at the time, before held or during the marriage bond of both parties. If this is not the case, then the disadvantaged are the Indonesian citizens themselves, whereas in accordance with the 1945 Constitution of Indonesia, that every citizen is equal in law and government, including the ownership of property in the form of Property Rights, Building Use Rights and Use Rights. Business.

Based on this fact, the study with the title Marriage Agreement on Joint Treasures in Mixed Marriage According to the Civil Code and Law Number 1 of 1974 Post Constitutional Court Decision Number 69/PUU-XIII/2015 is very urgent to do.

Based on the background of these problems, the legal issue in this study is whether Indonesian citizens who are married to foreigners are not entitled to joint property in the form of Ownership Rights, Business Permit or Building Use Rights. From these legal issues the following problems can be formulated, First, how is the position of the

${ }^{6}$ Read Decision of the Republic of Indonesia's Constitutional Court Number 69/PUU-XIII/2015, dated October 26, 2016 concerning Judicial Review of Law Number 5 of 1960 concerning Basic Regulations on Agrarian Principles and Law Number 1 of 1974 concerning Marriage to the 1945 Constitution 


\section{Prof. Dr. Titik Triwulan Tutik}

marriage agreement for property obtained during mixed marriages according to the Civil Code? Second, what is the position of the marriage agreement for property obtained during mixed marriages according to Law Number 1 of 1974 concerning Marriage? Third, what is the position of the marriage agreement for property obtained during mixed marriages after Constitutional Court Number 69/PUU-XIII/2015?

The research objectives are, First, to examine the position of the marriage agreement for property obtained during mixed marriages according to the Civil Code. Second, review the position of the marriage agreement for property obtained during mixed marriages according to Law Number 1 of 1974 concerning Marriage. Third, analyze the position of the marriage agreement for property obtained during a mixed marriage after the Constitutional Court Number 69/PUU-XIII/2015.

In accordance with the study focus of the problem, the theory used in this study includes the theory of citizenship in mixed marriages, and marriage agreement theories related to material rights. According to the Theory of Citizenship in Mixed Marriage, that the citizenship of husband/wife follows two theories, namely the theory of legal unity and the theory of equality. The theory of legal unity requires that the citizenship of the wife follow the status of the husband both when the marriage takes place and then after the marriage runs. Meanwhile, according to the theory of equality, that marriage does not affect a person's citizenship at all, in the sense that each of them (wife or husband) is free to determine their attitude in determining their citizenship or that the husband and wife continue to be citizens of origin even though they are husband and wife.

Meanwhile, according to the Marriage Agreement Theory is related to material rights, that the marriage agreement brings legal consequences to the separation of shared assets in the marriage. In other words, the purpose of making a marriage agreement is to make a deviation from the provisions regarding joint assets [Article 119 of the Indonesian Criminal Code]. With this, the parties are free to determine the legal form they want for the assets which are the object of their citizenship.

Some of the results of previous studies that are related to research conducted by researchers, and are the basis for developing research are; First, Damian Agata Yuvens's research from University of Indonesia 2016, with the title Critical Analysis of the Marriage Agreement in the Constitutional Court Decision Number 69/PUU-XIII/2015. The essence of the research is the examination of several provisions in the Law of the Republic of Indonesia Number 5 of 1960 concerning Basic Regulations on Agrarian Principles and the Law of the Republic of Indonesia Number 1 of 1974 concerning Marriage aimed at ensuring that Indonesian citizens married to citizens foreigners can continue to have land rights with the title Ownership Rights and Building Use Rights.

Second, I Nyoman Putu Budiartha's research from the University of Warmadewa Bali in 2017, with the title Law Enforcement Dilemma MK No.69 / PUU-XII / 2015 (Mixed Marriage Issues Without a Marriage Agreement), in essence, that a marriage agreement can be carried out during marriage. It can even be changed or revoked as long as both parties agree.

Third, Eva Dwinopianti's research from the 2017 Yogyakarta Islamic University of Indonesia, with the title Implications and Legal Effects of the Constitutional Court Ruling Number 69/PUU-XIII/2015 on Making Deed of Marriage After Marriage Agreement Made before a Notary, which essentially implies that the Constitutional Court Decision Number 69/PUU-XIII/2015 regarding the drafting of marriage agreements after marriage made before a Notary Public amend the legal mechanism for the making of a marriage agreement that can now be made as long as the marriage contract takes place by the Notary without having to be preceded by the establishment of an authorized court.

Based on the results of the previous research, although the research is similar to the position of the marriage agreement and property during the marriage, there are substantial differences with the author's research, because the issue of the author's research relates to whether Indonesian citizens who are married to foreigners are not entitled to joint property in the form of ownership rights, by focusing on; First, what is the position of the marriage agreement for property obtained during mixed marriages according to the Civil Code? Second, what is the position of the marriage agreement for property obtained during mixed marriages according to Law Number 1 of 1974 concerning Marriage? Third, what is the position of the marriage agreement for property obtained during mixed marriages after Constitutional Court Number 69/PUU-XIII/2015? So that the elaboration of the writer is not solely focused on the Constitutional Court Decision Number 69/PUU-XIII/2015, but also how Civil Law Studies, Marriage Law, Compilation of Islamic Law, and Islamic Law studies are expected to be more comprehensive.

The benefits of this research are contributing thoughts for the development of law, especially civil law both from the perspective of general civil law (BW) and Islamic civil law, especially family law concerning the position of marriage agreements on property obtained during marriage (theoretical aspects). It is also expected to be a 
reference for the preparation of further research, and at the same time be used as a reference for religious justice in decision making, especially concerning the distribution of assets obtained during marriage during divorce in order to provide legal protection to private rights (practical aspects).

In accordance with their background and purpose, research on a Marriage Agreement for Joint Assets in Mixed Marriage According to Law Number 1 of 1974 Post Constitutional Court Ruling Number 69/PUU-XIII/2015 is a normative (dogmatic) legal research, ${ }^{7}$ which intended to find and formulate legal arguments, ${ }^{8}$ through analysis of the main problem. While the approach used in this study there are 4 (four) types, namely: the statute approach; comparative approach, conceptual approach, and case approach.

The research steps undertaken are collecting legal materials, both primary and secondary legal materials related to the research topic. All secondary legal materials are recorded using a card system. The cards are arranged based on the main research problems and systematic writing that has been formulated.

All research results obtained from the legal materials mentioned above are searched for relationships between one another using deductive and inductive reasoning to produce propositions and concepts in the form of definitions, descriptions and classifications as a result of research.

\section{AGREEMENT OF MARRIAGE FOR JOINT TREASURE IN MIXED COUPLE MARRIAGE}

\subsection{MIXED MARRIAGE ACCORDING TO THE LEGAL SYSTEM IN INDONESIA}

Mixed marriages in Indonesia are regulated in three applicable legal provisions, namely the Civil Code for nonMuslims, and for Muslims regulated by the Marriage and Islamic Law which are adapted in the Compilation of Islamic Law (KHI).

Before the promulgation of the 1974 Marriage Law, mixed marriages were regulated by the Koninklijk Besluit dated 29 December 1896 No. 23. ${ }^{9}$ This regulation is called Regeling op de Gemengde Huwelijk which is better known as Gemengde Huwelijk Regeling, with the abbreviation G.H.R which is commonly referred to as Mixed Marriage Rules. ${ }^{10}$

The meaning of mixed marriages in accordance with Article 1 of the GHR is a marriage between "people" who are "in" Indonesia subject to different laws. This definition is very broad in scope, does not limit the meaning of mixed marriages in marriages between Indonesian citizens or between Indonesian marriages and marriages that take place in Indonesia, provided that the parties that hold marriages in Indonesia are subject to different laws which are mixed marriages. ${ }^{11}$

7 Legal Research includes Normative (Dogmatic) Research and Doctrinal Law Research. Normative (Dogmatic) Legal Research is research on statutory regulations, jurisprudence (case law), contracts, and legal values that live in a society that is sometimes also called empirical legal research. While Doctrinal Law Research is research on the principles of law, legal literature, the views of law graduates who have high qualifications, and comparative law activities. According to J. Gijssel, the Dogmatic Study of law focuses on positive law, including: (1) studying the rule of law from a technical perspective; (2) talk about law; (3) talk of law in terms of law; and (4) talk about concrete problems. See J. Gijssel in Philipus M. Hadjon, 1994, "Study of Dogmatic Legal Studies (Normative)", article in the Juridical Journal of the Faculty of Law, Airlangga University Vol. IX, No. 6, November-December 1994.

${ }^{8}$ Argumentation (argument) has two meanings: (1) "argument" means a series of reasoning (trains of reasoning); (2) "argument" refers to human interaction relating to the argumentation forum (eg court, scientific meeting, congress, etc.). Next on page h. 9. Three theories of legal argumentation are presented, namely: (1) logical argumentation theory based on the formal logic approach; (2) rhetorical argument theory, with a focus on the effectiveness of argumentation with language in combination; (3) dialogical argumentation theory, patterning legal argumentation as part of a discussion. In this dialogical approach combined with logic and rhetoric models. Ibid.

${ }^{9}$ Staatblad 1898 No. 158

${ }^{10}$ R. Soetojo Prawirohamidjojo, Pluralism in Marriage Legislation in Indonesia, Surabaya: Airlangga University Press, p.

${ }^{11}$ In this context it also includes marriages between two non-Indonesian citizens who hold marriages outside of Indonesia. For example, between Arab citizens with French citizens, including mixed marriages. But this meaning is too broad, because when marriage takes place there is absolutely no connection with Indonesian law, unless they later become Indonesian citizens.

International Journal of Research -GRANTHAALAYAH 


\section{Prof. Dr. Titik Triwulan Tutik}

In the definition of the provisions of Article 1 of the GHR, including marriage between two people who are Indonesian citizens who are in Indonesia subject to two different legal rules that carry out marriages outside Indonesia or also between an Indonesian citizen and a foreign citizen are also included mixed marriages. Except when parties or parties who were previously subject to all or part of the BW marriage law, then their marriage applies the provisions of Article 83 of the Civil Code.

Based on the provisions of Article 1 of the GHR and Article 83 of the Civil Code, those included in the definition of mixed marriages include:

1) between two Indonesian citizens, one belonging to the European group and the other to the Eastern Chinese group;

2) between two Indonesian citizens, one belonging to the Eastern Chinese foreign group and the other to the non-Chinese Eastern Eastern class;

3) between two Indonesian citizens including one European or Eastern Chinese foreigner and a foreign national.

In addition, according to the provisions of Article 1 of the GHR, marriages between two people in Indonesia that belong to the same group, but are subject to different laws also include mixed marriages. for example, Bumiputera (native inhabitants), people who are Christians and Bumiputera people who are Muslims. Likewise, with two Easterners besides Chinese, one of whom is an Indonesian citizen and the other a foreign national.

Now what about the definition of marriage according to the Marriage Law? The Marriage Law provides a slightly different definition from the definition of GHR provisions. The meaning of mixed marriages regulated in Article 57 of the Marriage Law is:

What is meant by mixed marriages in this Law is for marriages between two people who are subject to different laws in Indonesia, due to differences in citizenship and one of the parties is a foreign national and one of the parties is an Indonesian citizen.

Article 57 restricts the marriage of mixed marriages to marriages between an Indonesian citizen and a person who is not an Indonesian citizen, so that they include marriages between fellow citizens of different laws and between Indonesian non-citizens.

With the effectuation of Law Number 1 of 1974, the provisions stipulated in the GHR referred to as already stipulated in the Marriage Law are declared invalid. Because Article 57 of the Marriage Law Number 1 of 1974 emphasizes differences in citizenship and or subject to different laws, the provisions of the GHR still apply as long as the person performing the mixed marriage is a person as regulated in Article 57 of the Marriage Law No. 1 of 1974.12

Purnadi Purbacaraka and Agus Brotosusilo provide the definition of international marriage as follows:

International marriage is a marriage that contains elements of $u$ sing. The using element can be in the form of a bride having different citizenship with the other bride, or both brides having the same citizenship but the marriage takes place in another country or a combination of both. ${ }^{13}$

The difference in the law has caused several kinds of mixed marriages, namely:

1) Intergentiel Marriage explains which law or what law applies, if a marriage arises between 2 (two) people, each with the same or different nationality, who are subject to different legal regulations. For example, Indonesian citizens from Europe are married to native Indonesians.

2) Interlocal Mixed Marriage arranges legal relations (marriages) between native Indonesians from each customary environment. For example, Minang people marry Javanese.

3) Interreligious Mixed Marriage (interreligious) Regulates the legal relationship (marriage) between 2 (two) people, each of whom is subject to different religious law regulations. For example, Muslims with Christians. ${ }^{14}$

In the 1974 Marriage Law it has been determined that the legality of marriage in Indonesia is based on each religion and belief. ${ }^{15}$ Therefore regarding mixed marriages that are held in Indonesia must be done based on

12 Zain Badjeber, Question and Answer Marriage Law Issues, Jakarta: Sinar Harapan, 1985, p. 80

${ }_{13}$ Purnadi Purbacaraka, and Agus Brotosusilo, Joints of International Civil Law an Orientation, Jakarta: Raja Grafindo Persada, 1997, p. 36

${ }^{14}$ Titik Triwulan Tutik, Principles of Constitutional Law, Jakarta, Prestasi Pustaka Publisher, 2006, p. 242.

${ }^{15}$ See Article 2 paragraph 1 of the Marriage Law

International Journal of Research -GRANTHAALAYAH 
Indonesian marriage law so the marriages of marriage must be based on religious law and must be noted if both parties, the prospective husband and wife adhere to the same religion will not cause problems, but if different religions, then there will be legal problems between religions.

The problem will not be complicated if one party to merge/follow the religion of the other party by the willingness, but this difficulty arises if both parties still want to maintain their beliefs. Moreover, because the Civil Registry Office (now the Office of Population and Civil Registry) based on Presidential Decree Number 12 of 1983, no longer functions to marry off.

But in reality, it often happens for the couple to easily marry based on the religion of one party, and then after their marriage is ratified, they return to their respective beliefs. In Indonesia interfaith marriage is still a problem that still needs to be resolved as well as possible for its citizens.

Regarding the legitimacy of mixed marriages, there are no specific arrangements, so that in practice the citizenship often occurs and to facilitate the couple marry based on the religion of one party, but then after the marriage is ratified, they return to their respective beliefs. Besides that, there are also couples who have marriages abroad, only then registered in Indonesia.

Based on this, because the issue of mixed marriages is not possible to be eliminated, then for the existence of legal certainty as citizens, an arrangement is made regarding the validity of mixed marriages.

\subsection{MARRIAGE AGREEMENT FOR COMMON ASSETS IN MIXED MARRIAGE}

Mixed marriages actually carry quite complicated legal consequences, which are related to the position of the husband/wife, the position of children, and the position of property.

Article 2 of the GHR stipulates that a woman (wife) who engages in mixed marriage, as long as the marriage has not broken, is subject to the laws applicable to her husband, both public and private law. The point is that the wife follows the husband's legal status. From this provision it is clear that for the wife there is no other choice, other than submitting itself to the husband's law. In addition, this provision also does not provide freedom for the wife to determine which legal choices apply to her after she has made a mixed marriage. Having the husband's public legal position by his wife does not mean that the wife based on the provisions of Article 2 of the GHR obtains the citizenship of the sumi.

Whether the wife gains citizenship and/or loses her own citizenship, depends on the citizenship law of the husband and wife's country. According to the Indonesian Citizenship Law and the Citizenship Act in many other countries, the wife does not automatically obtain the husband's citizenship and lose his own citizenship. The wife may not lose her own citizenship and not obtain the husband's citizenship. Because the rights and obligations of the public (the right to choose and be elected, the right to obtain education, conscription, compulsory tax on foreigners, etc.) are generally related to citizenship, whereas citizenship is determined by the citizenship law. Then the GHR for a wife's public legal position can be said to have no meaning.

Article 11 of the GHR stipulates that children born of mixed marriages that have been carried out before the entry into force of the GHR, obtain the position of public and private law of their fathers. Whereas according to Article 12 of the GHR, the position of children referred to in Article 11 of the GHR as legitimate children of fathers and mothers cannot be disputed, because in the marriage certificate there are defects or because there is no marriage certificate, if the children are treated as legitimate children and the mother's father live openly as husband and wife.

Marriage Law 1974 Article 62 states, that in a mixed marriage the position of children is regulated in accordance with Article 59 paragraph (1), which states, "Citizenship obtained as a result of marriage or marriage terminates determines the applicable law, both regarding public law and civil law."

Regarding the citizenship status of children born from mixed marriages regulated in Article 4 letters $b$ to $f$ the Citizenship Act which is basically determined, that every child born second and/or one of his parents (father and/or mother) is an Indonesian citizen then he classified as an Indonesian citizen. Exceptions for children whose parents are of foreign nationality which results in the child having dual nationality, after they are 18 (eighteen) years of age or married, they must declare their choice of citizenship. ${ }^{16}$

Based on this provisions, basically the citizenship status of a child born from mixed marriages in which one of his parents is an Indonesian citizen is recognized as an Indonesian citizen until the person is 18 (eighteen) years old

\footnotetext{
${ }^{16}$ See article 6 paragraph (1) of the Citizenship Law

International Journal of Research -GRANTHAALAYAH
} 


\section{Prof. Dr. Titik Triwulan Tutik}

or has married so they have the right to choose their nationality. ${ }^{17}$ Even the loss of Indonesian citizenship to one of the parents of a child born from mixed marriages does not automatically apply to nationality until their citizenship is 18 (eighteen) years of age or married, unless the consequence of making the child dual citizenship - so they must state choose one of his citizenship. ${ }^{18}$

In the context of applicable law in Indonesia, the regulation of assets obtained during marriage is regulated in different legal provisions (plurality), namely Civil Law, especially for non-Muslim citizens and for Muslims citizens the provisions of the Marriage Law 1974, Instruction President Number 1 of 1991 concerning the Compilation of Islamic Law (hereinafter referred to as KHI) in addition to applying Islamic Law itself.

According to the provisions of the Civil Code, that basically the assets obtained during marriage become one, become joint property. In Article 119 of the Civil Code. Regarding property in marriage the 1974 Marriage Law, is regulated in Article 35 which states as follows:

1) Property obtained during marriage becomes joint property.

2) The inheritance of each husband and wife and the property obtained by each as a gift or inheritance are under each supervision as long as the parties do not specify otherwise.

Based on the provisions of Article 35 of the 1974 Marriage Law, that assets obtained by inheritance or gifts cannot be categorized as joint assets. This provision is in line with the word of God in Sura al-Nisa verse 32 which basically confirms that every man and woman has a part of what they are trying for themselves.

\section{ANALYSIS OF MARRIAGE AGREEMENT AGREEMENT IN THE POST-MIXED CONSTITUTIONAL COURT OF MARRIAGE NUMBER 69/PUU-XIII/2015}

\subsection{LEGAL ANALYSIS OF THE CONSTITUTIONAL COURT DECISION NUMBER 69/PUU-XIII/2015}

On October 27, 2016, the Constitutional Court (MK) had issued Decision Number 69/PUU-XIII/2015 which in its citizenship granted the request for judicial review of the provisions regarding the Marriage Agreement regulated in Article 29 paragraph (1), paragraph (3) and paragraph (4) Marriage Law 1974. The Constitutional Court's ruling has created a new legal norm related to the Marriage Agreement as follows

1) At the time, before it takes place or during marriage, both parties with mutual agreement can submit a written agreement that is ratified by the marriage registrar or notary, after which the contents also apply to third parties as long as the third party is involved.

2) The agreement cannot be ratified if it violates the limits of law, religion and decency.

3) The agreement is valid since the marriage is carried out, unless specified otherwise in the Marriage Agreement.

During the marriage, the marriage agreement can be regarding marriage assets or other agreements, can't be changed or revoked, except if from both parties there is an agreement to change or revoke, and the change or revocation does not harm a third party.

The provisions of Article 29 of the Marriage Law of 1974 following the Constitutional Court's Decision contain new legal norms regarding the Marriage Agreement, namely:

1) A Marriage Agreement Can Be Made After A Marriage Is Made;

2) Ratification of a Marriage Agreement by the Notary Public;

3) May be effective from the date of the Marriage Agreement;

4) Marriage agreements may be revoked

Materially, the Constitutional Court's decision above is a responsive legal ruling if this is related to Sellnic Nonet's legal theory which states that good law in modern society is law that responds to the wishes of its citizens. In this case, related to the petition which the constitutional rights of Indonesian citizens who have mixed marriages without a marriage agreement lose their constitutional rights to have a Right of Ownership (HGB) for land because

17 This provision differs from the provisions in Article 11 of the GHR and the previous citizenship law, namely Law Number 62 of 1958, in which the child's citizenship status follows the father's citizenship status.

${ }^{18}$ See article 25 of the Citizenship Law International Journal of Research -GRANTHAALAYAH 
there is no marriage agreement meaningful according to Article 35 paragraph (1) The 1974 Marriage Act took place joint property. Therefore, if an Indonesian citizen who conducts a mixed marriage without a marriage agreement when purchasing ownership rights/HGB rights on the land will also be owned by the foreign national of the husband or wife of the Indonesian citizen, even though the ownership rights/HGB on the land cannot be given to the foreigners according to Article 21 paragraph (3) and 26 paragraphs (1) of the Basic Agrarian Law 1960. This will clearly harm the mixed-married Indonesian citizen because even though as Indonesian citizens it is evidently prevented from ever having the Right of Ownership/HGB on the land.

With the decision of the Constitutional Court that permits a marriage agreement during the marriage bond which is in fact also a marriage agreement can take effect after the marriage takes place and can even be made changes or revocation as long as both parties (husband and wife) agree and not harm a third party. Of course, this legal ruling is a new legal instrument that gives a breath of fresh air to Indonesian citizens who engage in mixed marriages while still maintaining their citizens will be able and have the opportunity to have ownership rights/HGB on land, this is no longer in conflict or in accordance with their Constitutional Rights as regulated in Article $28 \mathrm{H}$ paragraph (4) of the 1945 Constitution.

\subsection{IMPLICATIONS OF THE CONSTITUTIONAL COURT DECISION NUMBER 69/PUU-XIII/2015}

The Constitutional Court verdicts, will obtain permanent and binding legal force since after being pronounced before an open public hearing, ${ }^{19}$ which means that, the Constitutional Court's decision immediately obtains permanent and binding legal force after being pronounced and no other legal remedies can be taken (final and binding). The legal consequences of the Constitutional Court Decision above which granted the Petitioner's petition were null and did not have binding legal force over a legal norm requested by the Petitioner, therefore in this case Article 29 paragraph (1), (3), and (4) Law The Marriage Law of 1974 is based on the Constitutional Court ruling above a conditional unconstitutional, so that such a ruling creates a new legal condition/norm (declarative constitutive) which in this case the $\mathrm{MK}$ as referred to by Hans Kelsen as a negative-legislator, so that the Constitutional Court Ruling is the same as the order constitution.

The legal force of the Constitutional Court's Decision consists of binding legal force, legal force of proof, and executive legal force. The legal force binding on the Constitutional Court's Decision is not only binding on litigants (interpartes), but also binding and/or intended for all citizens, state institutions/officials and legal entities within the territory of the Republic of Indonesia (erga omnes). Therefore, based on the explanation, the Constitutional Court's Decision also binds the Notary as the authority (official) in the drafting of the marriage agreement and the Office of Population and Civil Registration or the Office of Religious Affairs (KUA) as the official who has the authority to register the marriage agreement certificate.

The phenomenon that occurs in the community which is one of the considerations of the Constitutional Court to declare such articles as conditional unconstitutional as the Constitutional Court's legal considerations described above, this is only done by the Constitutional Court to provide legal certainty and justice guaranteed by the 1945 Constitution for the public for their constitutional rights in making an agreement (the principle of freedom of contract) in this case a marriage agreement, therefore the Constitutional Court through one of its authorities regulated in Article 24 C paragraph (1) of the 1945 Constitution is to examine the Law against The 1945 Constitution issued a progressive ruling to accommodate the legal needs of the community.

However, related to the recording of marriage agreements made throughout the marriage, it must also be noted that in practice there are still technical obstacles in recording the marriage agreement, this is because there are evidently civil registry officials who only hold technical instructions related to marriage registration, by ignoring the provisions of the applicable laws and regulations regarding the registration of marriage and the recording of the marriage agreement. This obstacle occurs because in the Form (Form F2.12) used to register the marriage there is no column regarding the marriage agreement. ${ }^{20}$

${ }^{19}$ Indonesia, Article 47 of Act Number 24 of 2003 concerning the Constitutional Court as amended by Act Number 8 of 2011 concerning Amendment to Law Number 24 of 2003 concerning the Constitutional Court

20 Alwesius, "Pembuatan Perjanjian Perkawinan Pasca Putusan Mahkamah Konstitusi", http://alwesius.blogspot.com/2016/11/pembuatan-perjanjian-perkawinan-pasca.html., diakses 11 November 2018 


\section{Prof. Dr. Titik Triwulan Tutik}

The drafting of a marriage agreement generally results in legal consequences for the status of the property as well as for any third party concerned. Regarding the status of the assets, that the marriage agreement results in the separation of assets which were previously shared assets into the property of each party and other assets which later arise after the date of the stipulation remain separated from one another, so that there is no status anymore shared property.

The validity of the marriage agreement has consequences for third parties, as stipulated in Article 152 of the Civil Code which reads: "The provisions contained in the marriage agreement, which contain deviations from unity according to the Law in whole or in part, will not pass to the party third, before the day the provisions are made in a general register, which must be held for that matter at the Registrar's Office of the District Court, which in the jurisdiction of the marriage has taken place, or, if the marriage takes place abroad, in the Registrar's Office where the marriage certificate is recorded ". From the above provisions it can be seen that a marriage agreement can also apply to third parties, after the marriage agreement is registered at the Registrar's Office of the District Court.

So, based on the provisions of Article 147 Juncto Article 152 of the Civil law it can be concluded that since the marriage took place the marriage agreement only applies to the parties who made it, namely husband and wife, whereas the marriage agreement only applies to third parties since it is registered at the Registrar's District Court.

\section{CONCLUSION}

Based on the decision of the Constitutional Court the marriage agreement comes into force since the marriage took place, unless otherwise specified in the marriage agreement. This means that if the parties do not specify when the marriage agreement will come into effect, then by law the marriage agreement will take effect from the time the marriage is concluded. Thus, the legal consequences of the status of joint property made a marriage agreement after marriage which began since the marriage took place followed by the status of shared property becomes separate if desired by both parties in the agreement, as well as the assets to be obtained in the future remain the property of each - each party, without having to obtain a court decision related to the separation of assets. Then the legal consequences of making a marriage agreement based on the Constitutional Court's Decision apply and bind a third party. The making of such a marriage agreement must not be detrimental to a third party, because the making of a marriage agreement as long as the marriage takes place brings legal consequences to changes in the legal status of property contained or obtained in the marriage.

\section{SOURCES OF FUNDING}

This research received no specific grant from any funding agency in the public, commercial, or not-for-profit sectors.

\section{CONFLICT OF INTEREST}

The author have declared that no competing interests exist.

\section{ACKNOWLEDGMENT}

None.

\section{REFERENCES}

[1] Abdurrahman. Kompilasi Hukum Islam. Jakarta: Akademika Presindo. 1995

[2] Al-Hadi, Abu Azam. "Perkawinan dalam Kompilasi Hukum Islam", Jurnal Hukum Islam al-Qanun Vol. 2, Desember 2001, Fakultas Syari'ah IAIN Sunan Ampel Surabaya, hal. 39-48

[3] Al-Jabry, Abdul Manan Muhammad. Jarimatuz-zawaj Bighairil-Muslimat: Fiqhan wa Siyasatan. Terj. Achmad Syathori. "Perkawinan Campuran Menurut Pandangan Islam". Jakarta: Bulan Bintang. 1988 
Marriage Agreement for The Joint Assets in Mixed Couple Marriage According in Indonesia Book of Civil Law Number 1 Of 1974 Post Decision of The Court of Constitution Number 69/Puu-Xiii/2015

[4] Alwesius, "Pembuatan Perjanjian Perkawinan Pasca Putusan Mahkamah Konstitusi", http://alwesius.blogspot.com/2016/11/pembuatan-perjanjian-perkawinan-pasca.html., _ diakses 11 November 2018

[5] Basyir, Ahmad Azhar. Hukum Perkawinan Islam. Jakarta: Rineka Cipta. 1997

[6] Campbell, Enid, (et.all), 1996, Legal Research, Sidney; The Law Book Company, Ltd.

[7] Damian Agata Yuvens, "Analisis Kritis terhadap Perjanjian Perkawinan dalam Putusan Mahkamah Konstitusi Nomor 69/PUU-XIII/2015", Artikel dalam Jurnal Konstitusi, Volume 14, Nomor 4, Desember 2017, hal. 799819

[8] Djazuli, A. Kaidah-Kaidah Fikih Kaidah-Kaidah Hukum Islam dalam Menyelesaikan Masalah-Masalah yang Praktis, Jakarta: Kencana Prenada Media Group, 2006

[9] Do'i, Abdul Rahman I. Shari'ah The Islamic Law, Terj. Basri Iba Asghary dan Wadi Masturi, "Perkawinan dalam Syari'at Islam", Jakarta: Rineka Cipta, 1996

[10] Eva Dwinopianti, "Implikasi dan Akibat Hukum Putusan Mahkamah Konstitusi Nomor 69/PUU-XIII/2015 terhadap Pembuatan Akta Perjanjian Perkawinan Setelah Kawin yang Dibuat di Hadapan Notaris", artikel dalam jurnal Lex Renaisannce No. 1 Vol. 2 Januari 2017, hal. 16 - 34

[11] Gautama, Sudargo. Hukum Perdata Internasional Indonesia. Bandung: Penerbit Alumni. 1995

[12] Hadjon, Philipus M. 1994, “Pengkajian Ilmu Hukum Dogmatik (Normatif)”, artikel dalam Jurnal Yuridika Fakultas Hukum Universitas Airlangga Vol. IX, No. 6, November-Desember 1994

[13] Hadjon, Philipus M., dan Tatiek Sri Djatmiati, 2005, Argumentasi Hukum, Yogyakarta; Gadjah Mada University Press

[14] Hasan, Djuhaedah. Hukum Keluarga Setelah Berlakunya Undang-Undang Nomor 1 Tahun 1974. Bandung: Armico. 1988

[15] Hasan, M. Ali. Azas-azas Hukum Islam: Pengantar Ilmu Hukum dan Tata Hukum Islam di Indonesia. Jakarta: Raja wali Press. 1997

[16] I Nyoman Putu Budiartha, "Dilema Penegakan Hukum Putusan MK No.69/PUU-XII/2015 (Persoalan Perkawinan Campuran Tanpa Perjanjian Kawin)”, artikel dalam Jurnal Notariil, Vol. 1, No. 2 Mei 2017, hal. 112

[17] Idri." Prosedur Pelaksanaan Perkawinan di Indonesia", Jurnal Hukum Islam al-Qanun Vol. 2, Desember 2001, Fakultas Syari'ah IAIN Sunan Ampel Surabaya, hal. 27-37

[18] Kaelany H.D., Islam dan Aspek-Aspek Kemasyarakatan, Bandung: Bumi Aksara, 1986

[19] Kuzairi, Achmad. Nikah sebagai Perikatan. Jakarta: RajaGrafindo Persada. 1995

[20] Mahdi, Sri Susilowati., Sjarif, Surini Ahlan dan Cahyono, Akhmad Budi. Hukum Perdata: Suatu Pengantar. Jakarta: Gitama Jaya Jakarta. 2005

[21] Manan, Abdul. Aneka Masalah Hukum Perdata Islam di Indonesia. Jakarta: Kencana. 2008

[22] Nuning Hallet, Mencermati Isi Rancangan UU Kewarganegaraan, http://www.mixedcouple.com, diakses 16 Juli 2009

[23] Prawirohamidjojo, R. Soetojo. Pluralisme Hukum Perkawinan di Indonesia. Surabaya: Airlangga University Press. 2000

[24] Prawirohamidjojo, R. Soetojo., dan Pohan, Marthalena. Hukum Orang dan Keluarga. Surabaya: Airlangga University Press. 2000

[25] Putusan Mahkamah RI Nomor 69/PUU-XIII/2015, tanggal 26 Oktober 2016 tentang Pengujian Materiil Undang-Undang Nomor 5 Tahun 1960 tentang Peraturan Dasar Pokok-Pokok Agraria dan Undang-Undang Nomor 1 Tahun 1974 tentang Perkawinan terhadap UUD NRI 1945

[26] Rofiq, Achmad. Hukum Islam di Indonesia. Jakarta: RajaGrafindo Persada. 1995

[27] Salim H.S. Pengantar Hukum Perdata Tertulis [BW]. Jakarta: Sinar Grafika. 2002

[28] Subekti. Pokok-Pokok Hukum Perdata. Jakarta: Internusa. 2000

[29] Syaltut, Mahmud. Al-Islam Aqidah wa Syari'ah. Terj. Fachruddin dan Nasharuddin Thaha. Akidah dan Syari'ah Islam. Jakarta: Bina Aksara. 1984

[30] Syarifuddin, Amir. Hukum Perkawinan Islam di Indonesia Antara Fiqh Munakahat dan Undang-Undang Perkawinan. Jakarta: Kencana. 2007

[31] Titik Triwlan Tutik. Konstruksi Hukum Tata Negara Indonesia Pascaamandemen UUD 1945, Jakarta; Kencana Prenada Media Group. 2017 
Prof. Dr. Titik Triwulan Tutik

[32] Titik Triwulan Tutik. Hukum Perdata dalam Sistem Hukum Nasional. Jakarta: Kencana Prenada Media Group. 2011

[33] Undang-Undang Nomor 1 Tahun 1974 tentang Perkawinan

[34] Undang-Undang Nomor 5 Tahun 1960 tentang Peraturan Dasar Pokok-Pokok Agraria. 